\title{
Are Biologics Safe in the Immediate Postoperative Period? A Single-Center Evaluation of Consecutive Crohn's Surgical Patients
}

\author{
Amy L. Lightner, M.D. ${ }^{1,2} \cdot$ Fabian Grass, M.D. ${ }^{2,3}$ • Ahmad M. Alsughayer, M.B.B.S. ${ }^{2}$ \\ William S. Harmsen, M.S. ${ }^{4}$ Molly Petersen, B.A. ${ }^{4}$ Edward V. Loftus Jr., M.D. ${ }^{5}$ \\ 1 Division of Colorectal Surgery, Cleveland Clinic, Cleveland, Ohio \\ 2 Department of Colon and Rectal Surgery, Mayo Clinic, Rochester, Minnesota \\ 3 Department of Visceral Surgery, Lausanne University Hospital, Lausanne, Switzerland \\ 4 Division of Biomedical Statistics and Informatics, Mayo Clinic, Rochester, Minnesota \\ 5 Division of Gastroenterology and Hepatology, Mayo Clinic, Rochester, Minnesota
}

BACKGROUND: There is no study to date examining the safety of initiating or restarting biologic therapy after major abdominal surgery for Crohn's disease.

OBJECTIVE: The purpose of this study was to determine differences in the rates of 90-day superficial surgical site infections, intra-abdominal sepsis, and overall postoperative infectious complications among patients who were initiated on or restarted a biologic within 90 days postoperatively compared with those who were not.

DESIGN: This was a retrospective cohort study.

SETTINGS: The study was conducted at an IBD referral center.

PATIENTS: Adult patients with Crohn's disease who received a biologic therapy within 90 days of a major abdominal operation between May 20, 2014, and December 31, 2018, were included.

MAIN OUTCOMES MEASURES: Ninety-day superficial surgical site infection, intra-abdominal sepsis, and overall postoperative infectious complications were measured.

Funding/Support: None reported.

Financial Disclosures: Dr Lightner received consultant fees from Takeda; Dr Loftus received research support from UCB, Takeda, Janssen, AbbVie, Amgen, Pfizer, Genentech, Seres Therapeutics, Receptos, Gilead, Celgene, Medimmune, and Robarts Clinical Trials and is a consultant for UCB, Takeda, Janssen, AbbVie, Amgen, Pfizer, Eli Lilly, Celltrion Healthcare, Bristol-Myers Squibb, Celgene, Genentech, Gilead, and Boehringer Ingelheim.

Correspondence: Amy L. Lightner, M.D., Department of Colorectal Surgery, Cleveland Clinic, 9500 Euclid Ave, Cleveland, OH 44195. Email: Lightna@ccf.org

Dis Colon Rectum 2020; 63: 934-943

DOI: 10.1097/DCR.0000000000001649

(c) The ASCRS 2020
RESULTS: A total of 680 patients with Crohn's disease were included: 351 were initiated on biologic therapy within 90 days after surgery and 329 were not. Patients exposed to biologic therapy postoperatively were younger $(p<0.001)$, had a lower BMI $(p=0.0014)$, were less often diabetic $(p=0.0011)$, and were more often exposed preoperatively to biologics $(p<0.0001)$ and immunomodulators $(p<0.0001)$ but not corticosteroids $(p=0.8399)$. Of those exposed postoperatively, nearly all $(93.7 \%)$ had been on a biologics preoperatively, and most resumed the same biologic (68.0\%). The median time to starting biologic therapy postoperatively was 31 days (range, 7-89 d).

Postoperative biologic exposure was not associated with an increased risk of superficial surgical site infection $(\mathrm{HR}=1.02$ (95\% CI, 0.95-1.09) per week; $p=0.59)$, intraabdominal sepsis ( $\mathrm{HR}=1.07$ (95\% CI, 0.99-1.16); $p=0.73)$, or overall postoperative infectious complications $(\mathrm{HR}=1.02(95 \% \mathrm{CI}, 0.98-1.07) ; p=0.338)$; the overall rates of each at 90 days was $13 \%, 8 \%$, and $28 \%$.

LIMITATIONS: The study was limited by its retrospective design and single-center data.

CONCLUSIONS: Postoperative initiation or resumption of biologic therapy did not increase 90-day rates of superficial surgical site infection, intra-abdominal sepsis, or total infectious complications after major abdominal surgery for Crohn's disease. See Video Abstract at http:// links.lww.com/DCR/B207.

¿SON SEGUROS LOS FÁRMACOS BIOLÓGICOS EN EL POSTOPERATORIO INMEDIATO? UNA EVALUACIÓN DE UN SOLO CENTRO DE PACIENTES QUIRÚRGICOS CONSECUTIVOS CON ENFERMEDAD DE CROHN

ANTECEDENTES: No hay ningún estudio hasta la fecha que examine la seguridad de iniciar o reiniciar la terapia 
biológica después de una cirugía abdominal mayor en enfermedad de Crohn.

OBJETIVO: Determinar las diferencias en las tasas a 90 días de infecciones del sitio quirúrgico superficial, sepsis intraabdominal y complicaciones infecciosas postoperatorias generales entre los pacientes en que se inició o reinició un biológico dentro de los 90 días después de la operación en comparación con aquellos que no lo recibieron.

DISEÑO: Estudio de cohorte retrospectivo.

ESCENARIO: Centro de referencia de enfermedad inflamatoria intestinal.

PACIENTES: Pacientes adultos con enfermedad de Crohn que recibieron una terapia biológica dentro de los 90 días de una operación abdominal mayor entre el 20 de mayo de 2014 y el 31 de diciembre de 2018.

PRINCIPALES MEDIDAS DE RESULTADO: Infección superficial del sitio quirúrgico, sepsis intraabdominal y complicaciones infecciosas postoperatorias generales a 90 días.

RESULTADOS: Se incluyeron un total de 680 pacientes con enfermedad de Crohn: 351 se iniciaron en terapia biológica dentro de los 90 días posteriores a la cirugía y 329 no. Los pacientes expuestos a terapia biológica después de la operación eran más jóvenes $(\mathrm{p}<0.001)$, tenían un índice de masa corporal más bajo $(p=0.0014)$, eran con menos frecuencia diabéticos $(p=0.0011)$ y estaban expuestos con mayor frecuencia preoperatoriamente a fármacos biológicos $(\mathrm{p}<0.0001)$ e inmunomoduladores $(\mathrm{p}<0.0001)$ pero no a corticosteroides $(\mathrm{p}=0.8399)$. De los expuestos postoperatoriamente, casi todos (93.7\%) habían estado en terapia biológica en el preoperatorio, y la mayoría reanudó la misma terapia biológica (68\%). La mediana de tiempo para comenzar la terapia biológica después de la operación fue de 31 días (rango, 7-89 días). La exposición biológica postoperatoria no se asoció con un mayor riesgo de infección superficial del sitio quirúrgico (HR 1.02 (0.95-1.09) por semana, $\mathrm{p}=0.59)$, sepsis intraabdominal. (HR: 1.07 (0.99-1.16), $\mathrm{p}=0.73$ ), o complicaciones infecciosas postoperatorias generales (HR: 1.02, intervalo de confianza del 95\% 0.98-1.07, $\mathrm{p}=0.338$ ); las tasas generales de cada uno a los 90 días fue del $13 \%, 8 \%$ y $28 \%$.

LIMITACIONES: Diseño retrospectivo, y datos de un centro único.

CONCLUSIONES: El inicio o la reanudación en el postoperatorio de la terapia biológica no aumentaron las tasas a 90 días de infección superficial de sitio quirúrgico, sepsis intraabdominal o complicaciones infecciosas totales después de una cirugía abdominal mayor por enfermedad de Crohn. Consulte el Video Resumen en http://links.lww.com/DCR/B207. (Traducción-Dr Jorge Silva Velazco)

KEY WORDS: Crohn's disease; Postoperative biologics; Restarting biologics.

$\mathrm{D}$ espite the ever expanding repertoire of medical therapies for Crohn's disease (CD), up to $60 \%$ of patients will require a major abdominal operation in their lifetime for medically refractory disease, and at least one third will require multiple operations for disease recurrence, especially in the presence of penetrating disease. ${ }^{1}$ Unfortunately, postoperative morbidity occurs in one third of patients, and $10 \%$ of patients experience intra-abdominal sepsis after an anastomosis. ${ }^{2,3}$ Thus, there has been significant effort to identify modifiable risk factors for postoperative morbidity to improve surgical options. One major area of focus has been the safety of biologics in the perioperative period.

Anti-tumor necrosis factor (TNF) agents remain the most well-studied biologics with regard to the effect on postoperative outcomes. The analysis of their impact on postoperative outcomes remains controversial, with some articles reporting an increased risk of postoperative complications with preoperative exposure to anti-TNF therapy ${ }^{2-5}$ and others reporting no increased risk of postoperative compilations. ${ }^{6-9}$ Similarly, data regarding postoperative outcomes in the setting of vedolizumab exposure also remain controversial, with some series finding a significant increase in postoperative morbidity, ${ }^{10-12}$ whereas others have not. ${ }^{13-15}$ Ustekinumab remains the most understudied biologic in this regard, with one multicenter retrospective review finding no increase in postoperative complications as compared to anti-TNF therapy ${ }^{16}$ and another retrospective single center series finding no difference in postoperative outcomes as compared with vedolizumab. ${ }^{17}$ Despite the large volume of articles reported on the topic, there are no consistent data to mandate holding biologics before a major abdominal operation or diverting an anastomosis intraoperatively.

Interestingly, there are no articles to date assessing the safety of restarting biologic therapy in the early postoperative period. As postoperative prophylaxis is growing in popularity because of trials demonstrating its use in decreasing postoperative recurrence of $\mathrm{CD}^{18}$ and new American Gastroenterological Association guidelines recommending the use of postoperative prophylaxis with biologic therapy in high-risk patients, the safety of initiating or resuming biologics therapy in the postoperative period becomes an important question to answer. ${ }^{19}$ Therefore, we collected data on 680 patients with CD undergoing major abdominal surgery to determine the differences in rates of 90-day postoperative superficial surgical site in- 
fections (sSSIs), intra-abdominal sepsis, and overall infectious complication rates in patients restarted on biologics within the first 90 days after surgery versus those who were not and the risk for a 90-day complication in the setting of a 30-day complication.

\section{PATIENTS AND METHODS}

After institutional review board approval, a retrospective chart review of the Mayo Clinic Rochester electronic medical chart system between May 20, 2014, and December 31, 2017, was performed. A list of all patients with CD who underwent a major abdominal operation was obtained as identified by International Classification of Diseases, Ninth Revision (555.x), and International Classification of Diseases, Tenth Revision, codes for CD (50.x) and Current Procedural Terminology codes for major abdominal surgery $(44120,44125,44130,44140,44141,44143$, 44144, 44145, 44146, 44147, 44150, 44151, 44155, 44156, 44157, 44158, 44160, 44180, 44187, 44188, 44202, 44204, 44205, 44206, 44207, 44208, 44210, 44211, 44212, 44227, 44310, 44314, 44316, 44320, 44340, 44345, 44346, 44615, 44620, 44625, 44626, 44640, 44650, 44660, 44661, 44799, 44950, 44790, 45110, 45111, 45112, 45113, 45114, 45119, 45120, 45136, 45395, 45397, 45800, 45805, 45820, 45825, 49000 ). Study patients included adults (aged $\geq 18 \mathrm{y}$ ) with CD who received an anti-TNF (infliximab, adalimumab, or certolizumab pegol), anti-integrin (vedolizumab), or anti-interleukin (ustekinumab) in the 90 days after a major abdominal operation. The control cohort included patients not exposed to biologic therapy in the 90 days after a major abdominal operation. Patients were excluded if they underwent an emergent operation or did not have at least 90 days of follow-up after their operation. Data abstracted included demographic and disease characteristics, including patient sex, age, BMI category $\left(<18.5 \mathrm{~kg} / \mathrm{m}^{2}\right.$ [underweight], $18.5-30.0 \mathrm{~kg} / \mathrm{m}^{2}$ [normal weight], and $>30.0 \mathrm{~kg} /$ $\mathrm{m}^{2}$ [obese]), smoking status, duration of $\mathrm{CD}$, previous intestinal resection, and predominant disease phenotype at operation. Preoperative serum laboratories within 4 weeks of surgery (leukocyte count, hemoglobin, platelet count, and albumin) and within 2 weeks of surgery (C-reactive protein) were collected. Data were collected on preoperative medication exposure to corticosteroids and immunomodulators (azathioprine, 6-mercaptopurine, and methotrexate) within 4 weeks of surgery and biologics (infliximab, adalimumab, certolizumab pegol, vedolizum$\mathrm{ab}$, and ustekinumab) within 12 weeks of surgery. History of previous biologic use and number of different biologics were also collected. Operative characteristics, including the operation performed (grouped by: A, ileostomy or colostomy formation; B, anastomosis with or without resection (ileocecectomy, segmental resection, colostomy closure, ileostomy closure, and subtotal colectomy with anastomosis); C, resection without anastomosis (colectomy, proctectomy, proctocolectomy, and ileoanal pouch excision with end ileostomy); and $\mathrm{D}$, local revision surgery (ileostomy revision, parastomal hernia, exploratory laparotomy, and no resection)), laparoscopic versus open approach, construction of anastomosis, and use of proximal diversion in the setting of an anastomosis were collected. Postoperative data collection included initiation of new biologic therapy, resumption of previous biologic therapy, time to restarting biologic from the date of surgery, corticosteroid taper, and 90-day postoperative morbidity. Recorded 90-day postoperative morbidity included sSSI, intra-abdominal septic complications (combination of deep space abscess or anastomotic leak), and any postoperative infectious complication (urinary tract infection, pneumonia, bacteremia, sSSI, or intra-abdominal sepsis). Dates of complications were also recorded. When looking at the association of 90-day complications after resuming or initiating biologic therapy, only complications occurring after the exposure to biologic were included.

The primary end points were the rates of 90-day sSSI, intra-abdominal sepsis, and overall postoperative infectious complications among patients who were initiated on or resumed biologic therapy within 90 days of surgery versus those who were not. Secondary end points included the risk for a 90-day complication in the setting of a 30day complication to assess the risk of repeated complications (vicious cycle) in a specific patient.

\section{Statistical Analysis}

Categorical variables were expressed as number (percentage) and continuous variables expressed as median (range). Demographic and clinical characteristics variables were compared between patients who restarted biologics postoperatively and those who did not using a $\chi^{2}$ test or Kruskal-Wallis test as appropriate.

The associations of patient risk factors with outcomes occurring within 90 days of surgery, including any infection $(\mathrm{n}=172)$, SSI $(\mathrm{n}=87)$, and the composite outcome of either intra-abdominal abscess or leak $(n=54)$, were assessed using Cox proportional hazard regression models. The primary risk factor of interest was restarting biologics. This was assessed considering the date of restarting biologics and was treated as a time-dependent covariate in the models. Kaplan-Meier estimates were reported as eventfree percentages with $95 \%$ CIs at 30 days. These estimates were displayed as cumulative incidence curves for the time to each event (ie, any infection, SSI, and intra-abdominal sepsis) to provide an easily assessable graphical overview on temporal aspects. The results of the Cox models were reported as HRs and 95\% CIs along with the corresponding $p$ values. Variables considered in the multivariable Cox models were chosen based on the univariate significance and differed according to event rate for the specific out- 
come of interest. For time to SSI, variables with $p<0.1$ and time to restarting biologics were included in the multivariable Cox model. For time to intra-abdominal sepsis, risk factors with $p<0.21$ were included in the multivariable Cox model. Lastly, for time to any infectious complications, all of the risk factors ran univariately were included in the multivariable Cox model. Only patients with complete data for all predictor variables were included in the respective multivariable models. The $\alpha$ level was set at $p<0.05$ for statistical significance. Analyses were done using SAS version 9.4 (SAS Institute Inc, Cary, NC) and R version 3.4.2 (https://www.r-project.org).

\section{RESULTS}

A total of 680 patients with CD were included in the analysis: 335 patients resumed or were initiated on biologic therapy within 90 days after surgery $(49.3 \%)$, and 345 patients $(50.7 \%)$ were not exposed to biologics within 90 days postoperative. On univariate analysis, patients who resumed or were initiated on biologic therapy postoperatively were younger $(p<0.001)$, had a lower BMI $(p=0.01)$, were less often diabetic $(p=0.003)$, underwent different operations $(p<0.001)$, and were more often exposed preoperatively to biologics $(p<0.0001)$ and immunomodulators $(p<0.0001)$ but not corticosteroids ( $p=0.90$; Table 1).Of those who were restarted on biologics postoperatively, nearly all $(93.7 \%)$ had been on a biologic preoperatively, and $6.6 \%$ had been exposed to 4 different types of biologics in the past. Most patients resumed the same biologic therapy as preoperative (68.4\%). The median time to starting biologic therapy postoperatively was 31 days (range, 7-89 d; Table 1 ).

Eighty-seven patients (13\%) experienced an sSSI. At 30,60 , and 90 days, $10 \%, 12 \%$, and $13 \%$ of the population had a sSSI, as shown in Figure 1A. These were more common in females (male: $\mathrm{HR}=0.6$ (95\% CI, 0.38-0.93); $p=0.02)$, patients with perianal disease $(\mathrm{HR}=1.60(95 \%$ CI, 1.04-2.46); $p=0.03$ ), patients who underwent a resection without anastomosi (colectomy/proctectomy/proctocolectomy/IPAA excision with end ileostomy; $\mathrm{HR}=0.57$ (95\% CI, 0.29-1.12); $p=0.0004$ ), those who had longer duration of disease (HR $=1.02$ (95\% CI, 1.01-1.04) per year; $p=0.007)$, and those with a greater BMI $(\mathrm{HR}=1.06$ (95\% CI, 1.03-1.09) per 1 unit; $p=0.0001$, all univariate; Table 2). This was confirmed by multivariable analysis: female sex (male: $\mathrm{HR}=0.58$ (95\% CI, 0.37-0.92); $p=0.02$ ), preoperative corticosteroids ( $\mathrm{HR}=1.89$ (95\% CI, $1.19-$ $3.02) ; p=0.01)$, longstanding disease $(\mathrm{HR}=1.02(95 \%$ CI, 1.01-1.04) per year; $p=0.01)$, and obesity $(\mathrm{HR}=1.05$ (95\% CI, 1.03-1.08) per 1 unit in BMI; $p=0.001$ ) were independent risk factors for sSSI, whereas resuming or initiating biologics had no impact (HR $=1.02(95 \% \mathrm{CI}$, 0.95-1.09) per week; $p=0.59$ ).
Fifty-four patients (8\%) experienced intra-abdominal sepsis within 90 days after surgery $(7 \%$ at $30 \mathrm{~d}, 8 \%$ at $60 \mathrm{~d}$; Fig. 1B). Intra-abdominal sepsis was more common in patients exposed to corticosteroids preoperatively $(\mathrm{HR}=2.19$ (95\% CI, 1.28-3.76); $p=0.004)$ and in older patients $(\mathrm{HR}=0.98(95 \% \mathrm{CI}, 0.96-1.00)$ per year; $p=0.03)$. Resuming or initiating biologics postoperatively was not associated with an increased risk of intra-abdominal sepsis $(\mathrm{HR}=1.07$ (95\% CI, 0.99-1.16) per week; $p=0.11$, all univariate; Table 3 ). This was confirmed by multivariable analysis, which revealed no significant association between biologic resumption or initiation and intra-abdominal sepsis (HR $=1.01$ (95\% CI, 0.94-1.10) per week; $p=0.73)$.

A total of 172 patients (25\%) experienced an infectious complication within 90 days. The cumulative incidence of any infectious complication was $20 \%$ at 30 days, $24 \%$ at 60 days, and $28 \%$ at 90 days (Fig. 1C). Infectious complications were more common in patients exposed to corticosteroids preoperatively ( $\mathrm{HR}=1.53$ (95\% CI, 1.12$2.11) ; p=0.0075)$ or who had a resection without anastomosis (colectomy/proctectomy/proctocolectomy/IPAA excision with end ileostomy; HR $=1.90$ (95\% CI, 1.103.29); $p=0.008$ ). Resuming or initiating biologics postoperatively was not associated with an increased risk of postoperative infectious complications $(\mathrm{HR}=1.02(95 \%$ CI, 0.98-1.07); $p=0.34$; all univariate). On multivariable analysis, the resumption or initiation of biologics was not associated with an increased risk of infectious complications ( $\mathrm{HR}=1.01$ (95\% CI, 0.92-1.10); $p=0.34$; Table 4).

A total of 296 patients had at least 1 complication between 0 and 30 days postoperatively, and 112 patients had at least 1 complication between 30 and 90 days postoperatively. At 90 days, $82 \%$ of the patients who experienced a complication between 0 and 30 days postoperatively did not experience a complication between 30 and 90 days. A patient who had a complication between 0 and 30 days postoperatively was on average $24 \%$ more likely have a complication between 30 and 90 days. However, this increased risk was not statistically significant $(\mathrm{HR}=1.24$ $(95 \%$ CI, $0.85-1.80) ; p=0.27)$. Risk factors for any 90 -day complication included the presence of active perianal disease at the time of surgery (HR $=1.89$ (95\% CI, 1.29$2.75) ; p=0.0001)$ and exposure to biologics before surgery (no exposure: $\mathrm{HR}=0.49(95 \% \mathrm{CI}, 0.25-0.96) ; p=0.04)$.

\section{DISCUSSION}

Although there has been a significant number of published reports on the safety of preoperative exposure to various medications with regard to adverse postoperative outcomes, there have been no case series to date examining the safety of resuming or intiating biologics after a major abdominal surgery for CD. As more patients are being exposed to initiating in the early postoperative period as pro- 
TABLE 1. Demographics

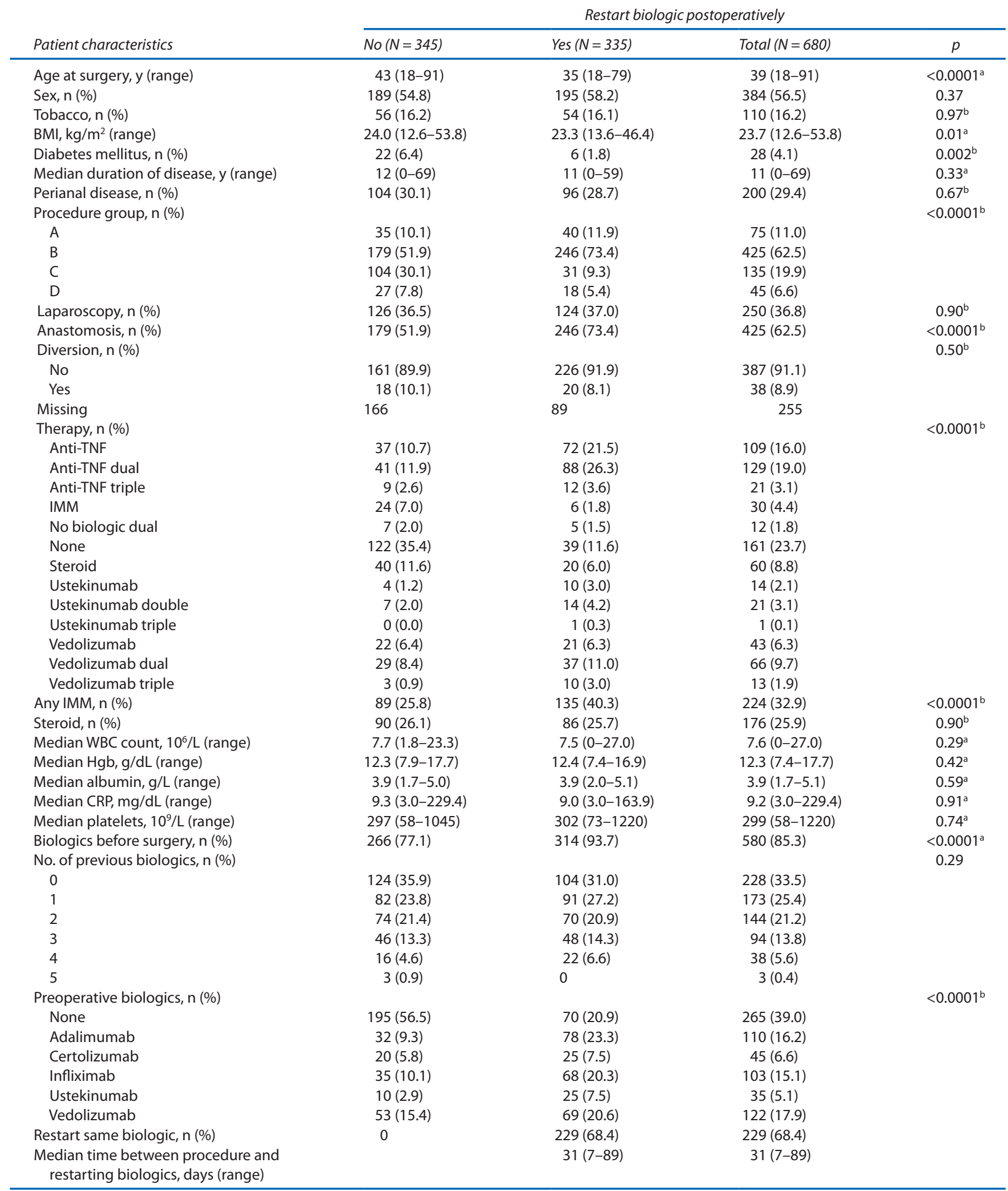

Procedure groups: $A$, stoma creation; $B$, anastomosis with or without resection; $C$, resection without anastomosis; $D$, local revision surgery. Anti-TNF = antitumor necrosis factor; IMM = immunomodulator; $\mathrm{WBC}=$ white blood cell; $\mathrm{Hgb}=$ hemoglobin; $\mathrm{CRP}=\mathrm{C}$-reactive protein .

a Data were calculated with the Kruskal-Wallis $p$ value.

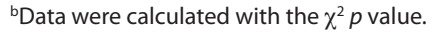




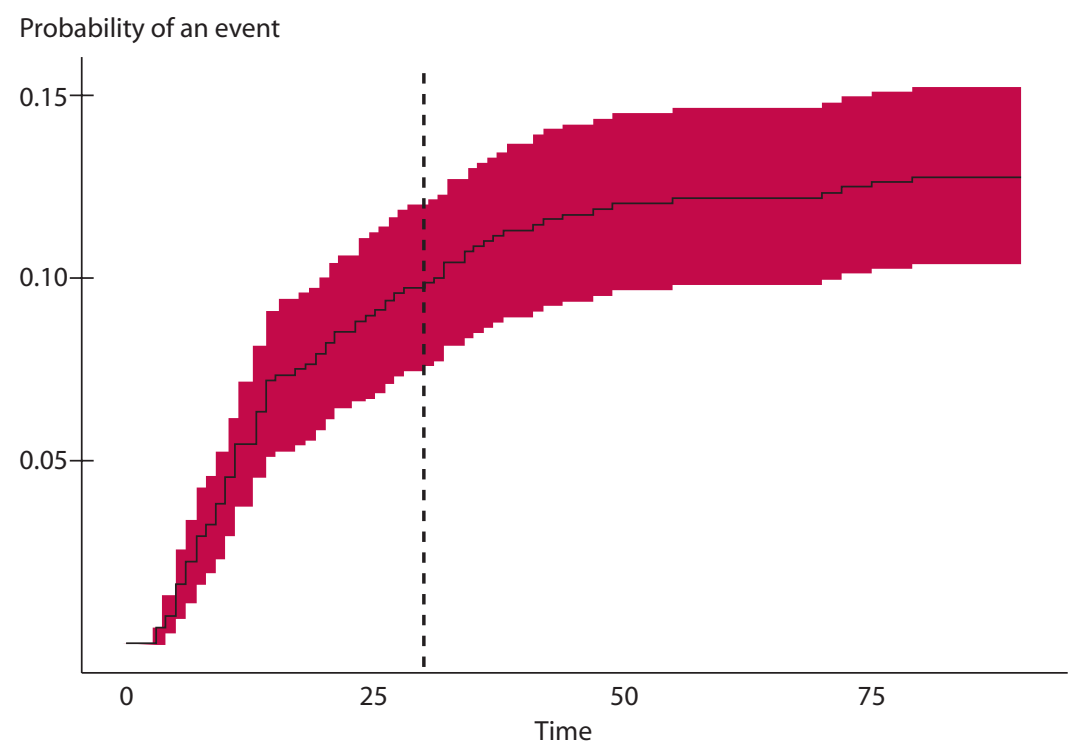

Probability of an event

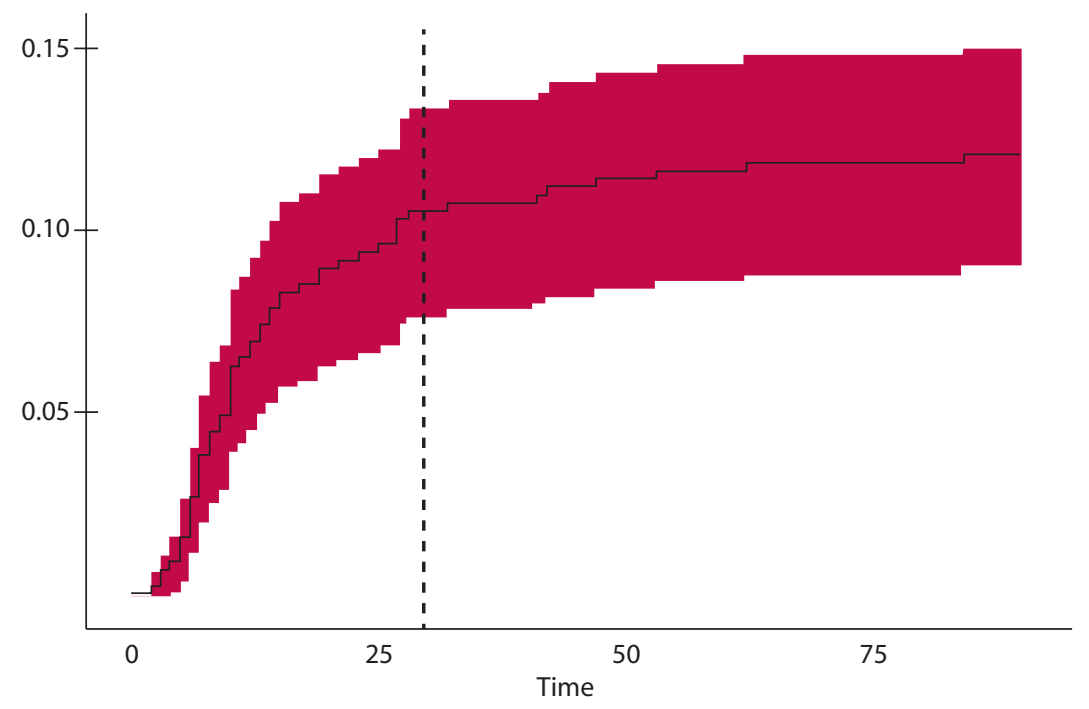

Probability of an event

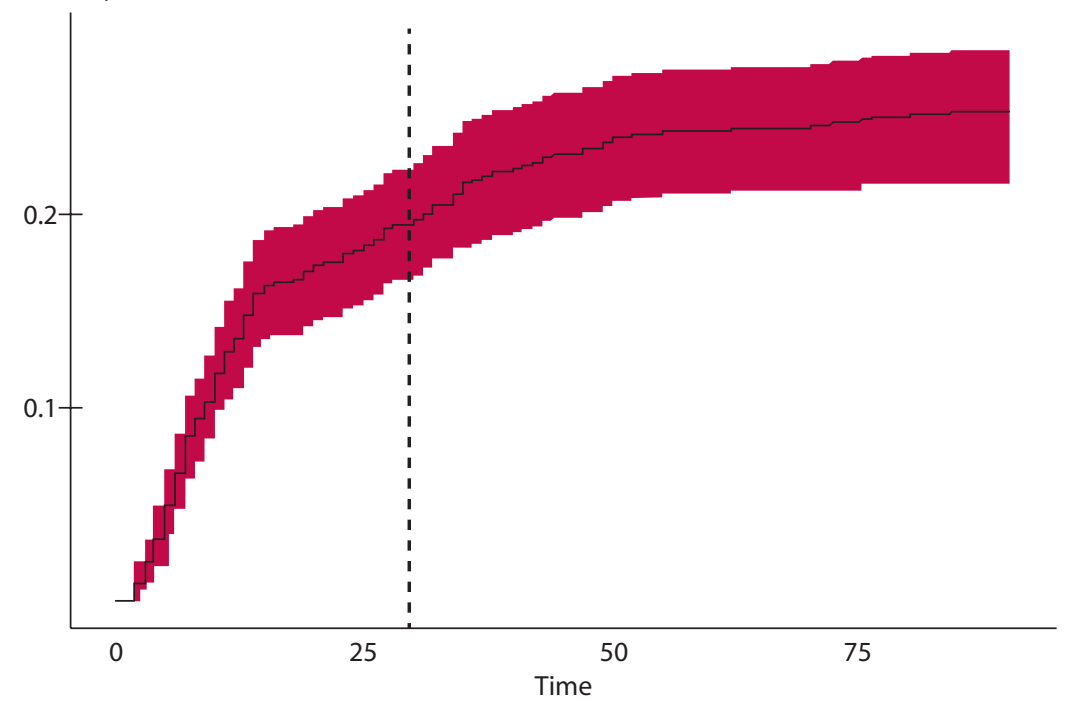

FIGURE 1. Cumulative incidence. A, Superficial surgical site infection. B, Intra-abdominal sepsis. C, Any infection. Displayed are Kaplan-Meier estimates (time-to-event analysis) with $95 \%$ Cls. The vertical dotted line represents the 30-day mark. 
TABLE 2. Risk factors for superficial surgical site infection

\begin{tabular}{|c|c|c|c|c|c|c|}
\hline \multirow[b]{2}{*}{ Variable } & \multirow[b]{2}{*}{ Events/total } & \multirow{2}{*}{$\begin{array}{l}\text { Cumulative incidence } \\
\text { estimates at } 90 \text { days }(95 \% \text { Cl) }\end{array}$} & \multicolumn{2}{|c|}{ Univariate Cox model } & \multicolumn{2}{|c|}{ Multivariable Cox model } \\
\hline & & & $H R(95 \% \mathrm{Cl})$ & $p$ & $H R(95 \% C l)$ & $p$ \\
\hline Overall & $87 / 680$ & $10(8-12)$ & & & & \\
\hline \multicolumn{7}{|l|}{ Sex } \\
\hline Female & $59 / 384$ & $12(8-15)$ & Reference & \multirow[t]{2}{*}{0.0242} & Reference & \multirow[t]{2}{*}{0.02} \\
\hline Male & $28 / 296$ & $7(4-10)$ & $0.60(0.38-0.93)$ & & $0.58(0.37-0.92)$ & \\
\hline \multicolumn{7}{|l|}{ Tobacco } \\
\hline No & $70 / 570$ & $9(7-11)$ & Reference & \multirow[t]{2}{*}{0.3496} & & \\
\hline Yes & $17 / 220$ & $14(7-20)$ & $1.29(0.76-2.19)$ & & & \\
\hline \multicolumn{7}{|l|}{ Diabetes mellitus } \\
\hline No & $82 / 652$ & $10(7-12)$ & Reference & \multirow[t]{2}{*}{0.4365} & & \\
\hline Yes & $5 / 28$ & $14(0-26)$ & $1.43(0.58-3.53)$ & & & \\
\hline \multicolumn{7}{|l|}{ Perianal disease } \\
\hline No & $53 / 480$ & $9(6-11)$ & Reference & \multirow[t]{2}{*}{0.0328} & Reference & \multirow[t]{2}{*}{0.20} \\
\hline Yes & $34 / 200$ & $12(8-17)$ & $1.60(1.04-2.46)$ & & $1.36(0.85-2.18)$ & \\
\hline \multicolumn{7}{|l|}{ Procedure group } \\
\hline A & $11 / 75$ & $11(3-17)$ & Reference & \multirow[t]{4}{*}{0.0004} & Reference & \\
\hline $\mathrm{B}$ & $37 / 425$ & $7(4-9)$ & $0.57(0.29-1.12)$ & & $0.60(0.30-1.23)$ & 0.16 \\
\hline $\mathrm{C}$ & $30 / 135$ & $18(11-24)$ & $1.58(0.79-3.16)$ & & $1.44(0.71-2.92)$ & 0.32 \\
\hline $\mathrm{D}$ & $9 / 45$ & $13(3-23)$ & $1.35(0.56-3.26)$ & & $1.24(0.49-3.16)$ & 0.35 \\
\hline \multicolumn{7}{|l|}{ Corticosteroids within 4 weeks } \\
\hline No & $58 / 504$ & $8(6-11)$ & Reference & \multirow[t]{2}{*}{0.0821} & Reference & \multirow[t]{2}{*}{0.01} \\
\hline Yes & $29 / 176$ & $14(9-19)$ & $1.49(0.95-2.32)$ & & $1.89(1.19-3.02)$ & \\
\hline \multicolumn{7}{|l|}{ Any IMM within 4 weeks } \\
\hline No & $59 / 456$ & $10(7-13)$ & Reference & \multirow[t]{2}{*}{0.8768} & & \\
\hline Yes & $28 / 224$ & $9(5-13)$ & $0.97(0.62-1.51)$ & & & \\
\hline \multicolumn{7}{|l|}{ Approach } \\
\hline Laparoscopic & $25 / 250$ & $7(4-10)$ & Reference & \multirow[t]{2}{*}{0.0991} & Reference & \multirow[t]{2}{*}{0.27} \\
\hline Open & $62 / 430$ & $11(8-14)$ & $1.48(0.93-2.35)$ & & $1.32(0.80-2.16)$ & \\
\hline \multicolumn{7}{|l|}{ Previous biologic } \\
\hline No & $8 / 100$ & $6(1-11)$ & $0.57(0.28-1.19)$ & \multirow[t]{2}{*}{0.1348} & & \\
\hline Yes & $79 / 580$ & $11(8-13)$ & Reference & & & \\
\hline Age, years & $87 / 680$ & & $1.01(1.00-1.02)$ & 0.1179 & & \\
\hline Duration of disease, years & $87 / 679$ & & $1.02(1.01-1.04)$ & 0.0070 & $1.02(1.01-1.04)$ & 0.01 \\
\hline BMI per 1 unit & $87 / 680$ & & $1.06(1.03-1.09)$ & 0.0001 & $1.05(1.03-1.08)$ & 0.0001 \\
\hline \multicolumn{3}{|c|}{$\begin{array}{l}\text { Time-dependent covariate time between procedure and restarting biologic } \\
\text { in weeks }\end{array}$} & $0.99(0.92-1.06)$ & 0.711 & $1.02(0.95-1.09)$ & 0.59 \\
\hline
\end{tabular}

Procedure groups: A, stoma creation; B, anastomosis with or without resection; $C$, resection without anastomosis; $D$, local revision surgery.

$\mathrm{IMM}=$ immunomodulatory.

phylaxis to guard against postoperative disease recurrence, the issue of whether resuming or initiating biologics is safe for a surgical patient has become increasingly important. It has now been established that postoperative prophylaxis significantly decreases endoscopic recurrence, ${ }^{18}$ important for patients with $\mathrm{CD}$ who are at high likelihood of surgical recurrence, putting them at risk for short bowel and lifelong total parenteral nutrition. ${ }^{1}$ We found that early postoperative exposure to biologic therapy was safe in the first month after surgery and did not increase the risk of sSSI, intra-abdominal abscess, or any infectious complication.

Thirteen percent of patients in our series experienced a 90-day postoperative sSSI, of whom the majority, $10 \%$, were diagnosed within the first 30 days after surgery. As has been found in previous studies, preoperative corticosteroids $s^{20}$ and obesity ${ }^{21}$ were independently associated with postoperative sSSI. In patients on corticosteroids or those with a high BMI, it may be especially important to perform a minimally inva- sive technique to limit open incisions, which are at a higher risk of infection ${ }^{22}$ and subsequent hernia formation. ${ }^{23}$ For those on corticosteorids, a postoperative taper should commence after surgery when able to prevent any additional infectious morbidity. Unlike previous studies, ${ }^{2,5,11,24}$ there was no increased risk based on biologic exposure.

Similar to previous literature on surgery in $\mathrm{CD}$, the cumulative rate of intra-abdominal abscess at 90 days was $8 \%$, with the majority of cases occurring in the first 30 days after surgery. Although the literature regarding exposure to biologics in the preoperative period and risk of postoperative intra-abdominal sepsis remains controversial, our data suggest that resumption or initiation of biologics in the postoperative period is safe and unaffected by exposure to biologics. Rather, corticosteroids were a significant risk factor for postoperative intra-abdominal sepsis, as has been found in previous studies.

Overall, $25 \%$ of patients experienced a postoperative infectious complication. These were more common in pa- 
TABLE 3. Risk factors for intra-abdominal sepsis

\begin{tabular}{|c|c|c|c|c|c|c|}
\hline \multirow[b]{2}{*}{ Variable } & \multirow[b]{2}{*}{ Events/total } & \multirow{2}{*}{$\begin{array}{c}\text { Cumulative incidence } \\
\text { estimates at } 90 \text { days ( } 95 \% \text { Cl) }\end{array}$} & \multicolumn{2}{|c|}{ Univariate Cox model } & \multicolumn{2}{|c|}{ Multivariable Cox model } \\
\hline & & & $H R(95 \% C l)$ & $p$ & $H R(95 \% \mathrm{Cl})$ & $p$ \\
\hline Overall & $54 / 680$ & $7(5-9)$ & & & & \\
\hline Female & $26 / 384$ & $6(4-9)$ & Reference & \multirow[t]{2}{*}{0.2003} & Reference & \multirow[t]{2}{*}{0.40} \\
\hline Male & $28 / 296$ & $8(5-11)$ & $1.42(0.83-2.42)$ & & $1.28(0.72-2.25)$ & \\
\hline \multicolumn{7}{|l|}{ Tobacco } \\
\hline \multicolumn{7}{|l|}{ Diabetes mellitus } \\
\hline No & $52 / 652$ & $7(5-9)$ & Reference & \multirow[t]{2}{*}{0.8553} & & \\
\hline Yes & $2 / 28$ & $7(0-16)$ & $0.88(0.21-3.60)$ & & & \\
\hline \multicolumn{7}{|l|}{ Perianal disease } \\
\hline No & $37 / 480$ & $7(4-9)$ & Reference & \multirow[t]{2}{*}{0.7278} & & \\
\hline Yes & $17 / 200$ & $7(4-11)$ & $1.11(0.62-1.97)$ & & & \\
\hline \multicolumn{7}{|l|}{ Corticosteroids within 4 weeks } \\
\hline No & $31 / 504$ & $5(3-7)$ & Reference & \multirow[t]{2}{*}{0.0044} & Reference & \multirow[t]{2}{*}{0.21} \\
\hline Yes & $23 / 176$ & $11(7-16)$ & $2.19(1.28-3.76)$ & & $1.46(0.81-2.62)$ & \\
\hline \multicolumn{7}{|l|}{ Any IMM within 4 weeks } \\
\hline No & $34 / 456$ & $7(4-9)$ & Reference & \multirow[t]{2}{*}{0.5143} & & \\
\hline Yes & $20 / 224$ & $8(4-11)$ & $1.20(0.69-2.09)$ & & & \\
\hline \multicolumn{7}{|l|}{ Approach } \\
\hline Laparoscopic & $17 / 250$ & $6(3-9)$ & Reference & \multirow[t]{2}{*}{0.3919} & & \\
\hline Open & $37 / 430$ & $7(5-10)$ & $1.29(0.72-2.28)$ & & & \\
\hline \multicolumn{7}{|l|}{ Previous biologic } \\
\hline No & $7 / 100$ & $6(1-11)$ & $0.85(0.39-1.89)$ & \multirow[t]{2}{*}{0.6963} & & \\
\hline Yes & $47 / 580$ & $7(5-9)$ & Reference & & & \\
\hline
\end{tabular}

Procedure groups: A, stoma creation; $B$, anastomosis with or without resection; $C$, resection without anastomosis; $D$, local revision surgery.

$\mathrm{IMM}=$ immunomodulatory.

tients exposed to corticosteroids but not affected by exposure to biologic therapy. This contradicts some of the literature suggesting that preoperative exposure to biologic therapy increases the risk of postoperative complications. Perhaps the complications are not a direct result of the biologic itself, but rather patient severity of disease, for which biologic therapy is a surrogate marker.

Interestingly, having a complication at 30 days did not portend a complication at 90 days. More than $80 \%$ who experienced a complication at 30 days did not experience a 30- to 90-day complication. Patients experiencing a 30-day complication are not more prone to complicated recovery later on. However, although not statistically significant, a patient who had a 30 -day complication was at a $24 \%$ increased risk of a 30- to 90-day complication, underscoring the need for postoperative outpatient care coordinator pathways to prevent delays in diagnosing additional past 30-day complications. The additional complications seen at 3090 days also suggest that perhaps we should be examining 90-day complication rates in the surgical literature rather than 30-day complications alone. Interestingly, risk factors for 30- and 90-day complications differed; risk factors for any 30-day infectious complication were type of operation and obesity, and risk factors for any 90-day infectious complication included the presence of perianal disease at the time of operation and preoperative exposure to biologic therapy. This also suggests that it may be important to understand surgical complications all the way to a 90 -day postoperative interval.

The majority of patients restarted on a biologic after surgery had been on a biologic preoperatively and most were receiving the same biologic preoperatively. This suggests the desire to reduce antibody formation by long delays in resumption of biologic therapy, ${ }^{25}$ as well as the desire to continue on the same class of biologic until there is true loss of response $\mathrm{e}^{26-29}$ or secondary loss of response $\mathrm{e}^{30,31}$ 
TABLE 4. Risk factors for any infectious complication

\begin{tabular}{|c|c|c|c|c|c|c|}
\hline \multirow[b]{2}{*}{ Variable } & \multirow[b]{2}{*}{ Events/total } & \multirow{2}{*}{$\begin{array}{c}\text { Cumulative incidence } \\
\text { estimates at } 90 \text { days }(95 \% \mathrm{Cl})\end{array}$} & \multicolumn{2}{|c|}{ Univariate Cox model } & \multicolumn{2}{|c|}{ Multivariable Cox model } \\
\hline & & & $H R(95 \% \mathrm{Cl})$ & $p$ & $H R(95 \% \mathrm{Cl})$ & $p$ \\
\hline Overall & $172 / 680$ & $20(17-23)$ & & & & \\
\hline Female & $106 / 384$ & $21(17-25)$ & Reference & \multirow[t]{2}{*}{0.1189} & Reference & \multirow[t]{2}{*}{0.42} \\
\hline Male & $66 / 296$ & $18(13-22)$ & $0.78(0.58-1.06)$ & & $1.27(0.71-2.29)$ & \\
\hline \multicolumn{7}{|l|}{ Tobacco } \\
\hline \multicolumn{7}{|l|}{ Diabetes mellitus } \\
\hline No & $164 / 652$ & $19(16-22)$ & Reference & \multirow[t]{2}{*}{$0.7051^{1}$} & Reference & \multirow[t]{2}{*}{0.65} \\
\hline Yes & $8 / 28$ & $25(7-39)$ & $1.15(0.56-2.33)$ & & $1.57(0.26-9.43)$ & \\
\hline \multicolumn{7}{|l|}{ Perianal disease } \\
\hline No & $112 / 480$ & $19(15-32)$ & Reference & \multirow[t]{2}{*}{0.0736} & Reference & \multirow[t]{2}{*}{0.28} \\
\hline Yes & $60 / 200$ & $22(16-28)$ & $1.33(0.97-1.82)$ & & $1.44(0.74-2.78)$ & \\
\hline $\mathrm{D}$ & $11 / 45$ & $20(7-31)$ & $1.07(0.50-2.29)$ & 0.0008 & $1.56(0.09-27.05)$ & 0.76 \\
\hline \multicolumn{7}{|l|}{ Preoperative corticosteroid } \\
\hline No & $114 / 504$ & $17(14-20)$ & Reference & \multirow[t]{2}{*}{0.0075} & Reference & \multirow[t]{2}{*}{0.09} \\
\hline Yes & $58 / 176$ & $27(20-33)$ & $1.54(1.12-2.11)$ & & $1.71(0.93-3.16)$ & \\
\hline \multicolumn{7}{|l|}{ Any IMM } \\
\hline No & $116 / 456$ & $20(16-24)$ & Reference & \multirow[t]{2}{*}{0.9137} & Reference & \multirow[t]{2}{*}{0.20} \\
\hline Yes & $56 / 224$ & $29(14-24)$ & $0.98(0.71-1.35)$ & & $1.49(0.81-2.72)$ & \\
\hline \multicolumn{7}{|l|}{ Approach } \\
\hline Laparoscopic & $54 / 250$ & $26(11-20)$ & Reference & \multirow[t]{2}{*}{0.0850} & Reference & \multirow[t]{2}{*}{0.48} \\
\hline Open & $118 / 430$ & $22(18-26)$ & $1.33(0.96-1.83)$ & & $1.25(0.68-2.28)$ & \\
\hline Previous biologic & & & & & & \\
\hline No & $18 / 100$ & $16(8-23)$ & $0.66(0.41-1.08)$ & 0.0994 & $0.89(0.37-2.16)$ & 0.80 \\
\hline Yes & $154 / 580$ & $20(17-24)$ & Reference & & Reference & \\
\hline
\end{tabular}

Procedure groups: A, stoma creation; B, anastomosis with or without resection; $C$, resection without anastomosis; $D$, local revision surgery.

$\mathrm{IMM}=$ immunomodulatory.

before switching to another class of biologic. The current trend is for an increasing use of postoperative prophylaxis given the high rates of endoscopic, clinical, and surgical recurrence after $\mathrm{CD}^{19}$ and the desire for bowel preservation.

There are several limitations to our analysis worth mentioning. First, this is a single-center retrospective review performed at a large IBD referral center where patients are typically referred after failing multiple immunosuppressive agents and present with severe or uncontrolled disease. Thus, our findings may not be applicable to patient populations treated at other centers. Second, we considered any complication after exposure to biologic as potentially related to the biologic, regardless of whether it occurred 2 days or 2 weeks after the biologic was administered. Thus some of the included complications after biologics may be unrelated to the biologic itself. Third, there were not enough events in this data set to say whether restarting a biologic is safe at 1 week versus 4 weeks versus 12 weeks after surgery. Rather, all of the events were grouped together. Fourth, there were similarly not enough events to compare the safety of different classes of biologics, including anti-TNF (infliximab, adalimumab, and certolizumab pegol), anti-integrin (vedolizumab), or anti-interleukin (ustekinumab). One class of biologic may behave differently than another with regard to postoperative infectious outcomes.

\section{CONCLUSION}

Resumption or initiation of biologics in the postoperative period for prophylaxis appeared safe with no added morbidity. However, corticosteroid exposure remained significantly associated with adverse postoperative outcomes. Future prospective, multicenter data would be useful to ascertain differences from time of surgery to postoperative biologic exposure and class of biologic to better understand the safety of postoperative biologic exposure. 


\section{REFERENCES}

1. Simillis C, Yamamoto T, Reese GE, et al. A meta-analysis comparing incidence of recurrence and indication for reoperation after surgery for perforating versus nonperforating Crohn's disease. Am J Gastroenterol. 2008;103:196-205.

2. Brouquet A, Maggiori L, Zerbib P, et al.; GETAID chirurgie group. Anti-TNF therapy is associated with an increased risk of postoperative morbidity after surgery for ileocolonic Crohn Disease: results of a prospective nationwide cohort. Ann Surg. 2018;267:221-228.

3. de Buck van Overstraeten A, Eshuis EJ, Vermeire S, et al. Shortand medium-term outcomes following primary ileocaecal resection for Crohn's disease in two specialist centres. Br J Surg. 2017;104:1713-1722.

4. Appau KA, Fazio VW, Shen B, et al. Use of infliximab within 3 months of ileocolonic resection is associated with adverse postoperative outcomes in Crohn's patients. J Gastrointest Surg. 2008;12:1738-1744.

5. Billioud V, Ford AC, Tedesco ED, Colombel JF, Roblin X, Peyrin-Biroulet L. Preoperative use of anti-TNF therapy and postoperative complications in inflammatory bowel diseases: a meta-analysis. J Crohns Colitis. 2013;7:853-867.

6. Colombel JF, Loftus EV Jr, Tremaine WJ, et al. The safety profile of infliximab in patients with Crohn's disease: the Mayo clinic experience in 500 patients. Gastroenterology. 2004;126:19-31.

7. Fumery M, Seksik P, Auzolle C, et al.; REMIND study group investigators. Postoperative complications after ileocecal resection in Crohn's disease: a prospective study from the REMIND group. Am J Gastroenterol. 2017;112:337-345.

8. Kotze PG, Magro DO, Martinez CAR, et al. Adalimumab and postoperative complications of elective intestinal resections in Crohn's disease: a propensity score case-matched study. Colorectal Dis. 2017;20:211-218.

9. Kotze PG, Saab MP, Saab B, et al. Tumor necrosis factor alpha inhibitors did not influence postoperative morbidity after elective surgical resections in Crohn's disease. Dig Dis Sci. 2017;62:456-464.

10. Lightner AL, Mathis KL, Tse CS, et al. Postoperative outcomes in vedolizumab-treated patients undergoing major abdominal operations for inflammatory bowel disease: retrospective multicenter cohort study. Inflamm Bowel Dis. 2018;24:871-876.

11. Lightner AL, McKenna NP, Tse CS, Raffals LE, Loftus EV Jr, Mathis KL. Postoperative outcomes in vedolizumab-treated Crohn's disease patients undergoing major abdominal operations. Aliment Pharmacol Ther. 2018;47:573-580.

12. Lightner AL, Raffals LE, Mathis KL, et al. Postoperative outcomes in vedolizumab-treated patients undergoing abdominal operations for inflammatory bowel disease. J Crohns Colitis. 2017;11:185-190.

13. Ferrante M, de Buck van Overstraeten A, Schils N, et al. Perioperative use of vedolizumab is not associated with postoperative infectious complications in patients with ulcerative colitis undergoing colectomy. J Crohns Colitis. 2017;11:1353-1361.

14. Law CCY, Narula A, Lightner AL, McKenna NP, Colombel JF, Narula N. Systematic review and meta-analysis: preoperative vedolizumab treatment and postoperative complications in patients with inflammatory bowel disease. J Crohns Colitis. 2018;12:538-545.

15. Yamada A, Komaki Y, Patel N, et al. Risk of postoperative complications among inflammatory bowel disease patients treated preoperatively with vedolizumab. Am J Gastroenterol. 2017;112:1423-1429.

16. Lightner AL, McKenna NP, Tse CS, et al. Postoperative outcomes in ustekinumab-treated patients undergoing abdominal operations for Crohn's disease. J Crohns Colitis. 2018;12:402-407.

17. Novello M, Stocchi L, Holubar S, et al. Surgical outcomes of patients treated with ustekinumab vs. vedolizumab in inflammatory bowel disease: a matched case analysis. Int J Colorectal Dis. 2019;34:451-457.

18. Regueiro M, Feagan BG, Zou B, et al.; PREVENT Study Group. Infliximab reduces endoscopic, but not clinical, recurrence of Crohn's disease after ileocolonic resection. Gastroenterology. 2016;150:1568-1578.

19. Nguyen GC, Loftus EV Jr, Hirano I, Falck-Ytter Y, Singh S, Sultan S; AGA Institute Clinical Guidelines Committee. American Gastroenterological Association Institute guideline on the management of Crohn's disease after surgical resection. Gastroenterology. 2017;152:271-275.

20. Ferrante M, D'Hoore A, Vermeire S, et al. Corticosteroids but not infliximab increase short-term postoperative infectious complications in patients with ulcerative colitis. Inflamm Bowel Dis. 2009;15:1062-1070.

21. Cai X, Shen W, Guo Z, et al. Thickness of subcutaneous fat is a predictive factor of incisional surgical site infection in Crohn's disease surgery: a retrospective study. Gastroenterol Res Pract. 2018;2018:1546075.

22. Maartense S, Dunker MS, Slors JF, et al. Laparoscopic-assisted versus open ileocolic resection for Crohn's disease: a randomized trial. Ann Surg. 2006;243:143-150.

23. Walming S, Angenete E, Block M, Bock D, Gessler B, Haglind E. Retrospective review of risk factors for surgical wound dehiscence and incisional hernia. BMC Surg. 2017;17:19.

24. Kopylov U, Ben-Horin S, Zmora O, Eliakim R, Katz LH. Anti-tumor necrosis factor and postoperative complications in Crohn's disease: systematic review and meta-analysis. Inflamm Bowel Dis. 2012;18:2404-2413.

25. Boehncke WH, Brembilla NC. Immunogenicity of biologic therapies: causes and consequences. Expert Rev Clin Immunol. 2018;14:513-523.

26. Hanauer SB, Feagan BG, Lichtenstein GR, et al.; ACCENT I Study Group. Maintenance infliximab for Crohn's disease: the ACCENT I randomised trial. Lancet. 2002;359:1541-1549.

27. Hanauer SB, Sandborn WJ, Rutgeerts P, et al. Human antitumor necrosis factor monoclonal antibody (adalimumab) in Crohn's disease: the CLASSIC-I trial. Gastroenterology. 2006;130:323-333; quiz 591.

28. Colombel JF, Sandborn WJ, Rutgeerts P, et al. Adalimumab for maintenance of clinical response and remission in patients with Crohn's disease: the CHARM trial. Gastroenterology. 2007;132:52-65.

29. Sandborn WJ, Feagan BG, Stoinov S, et al.; PRECISE 1 Study Investigators. Certolizumab pegol for the treatment of Crohn's disease. N Engl J Med. 2007;357:228-238.

30. Rutgeerts P, Feagan BG, Lichtenstein GR, et al. Comparison of scheduled and episodic treatment strategies of infliximab in Crohn's disease. Gastroenterology. 2004;126:402-413.

31. Sandborn WJ, Rutgeerts P, Enns R, et al. Adalimumab induction therapy for Crohn disease previously treated with infliximab: a randomized trial. Ann Intern Med. 2007;146:829-838. 